\title{
The history, current state and perspectives of aerosol therapy
}

\author{
BARTŁOMIEJ ROSPOND ${ }^{1}$ \\ AGATA KRAKOWSKA ${ }^{1, *}$ \\ BOŻENA MUSZYŃSKA ${ }^{2}$ \\ WŁODZIMIERZ OPOKA ${ }^{1}$ \\ ${ }^{1}$ Department of Inorganic and Analytical \\ Chemistry, Faculty of Pharmacy \\ Jagiellonian University Medical College \\ 30-688 Kraków, Poland \\ ${ }^{2}$ Department of Pharmaceutical Botany \\ Faculty of Pharmacy, Jagiellonian \\ University Medical College, 30-688 \\ Kraków, Poland
}

Accepted June 9, 2021

Published online June 9, 2021

\begin{abstract}
Nebulization is a very effective method of drug administration. This technique has been popular since ancient times when inhalation of plants rich in tropane alkaloids with spasmolytic and analgesic effects was widely used. Undoubtedly, the invention of anasthesia in the 19th century had an influence on the development of this technique. It resulted in the search for devices that facilitated anasthesia such as pulveriser or hydronium. From the second half of the 21st century, when the first DPI and MDI inhalers were launched, the constant development of aerosol therapy has been noticed. This is due to the fact that nebulization, compared with other means of medicinal substance application (such as oral and intravenous routes of administration), is safer and it exhibits a positive dose/efficacy ratio connected to the reduction of the dose. It enables drugs administration through the lung and possesses very fast onset action. Therefore, various drugs prescribed in respiratory diseases (such as corticosteroids, $\beta$-agonists, anticholinergics) are present on the market in a form of an aerosol.
\end{abstract}

Keywords: inhalation, nebulization, plant raw materials, metered-dose inhalers and dry-powder inhalers

\section{The history of aerosol therapy use}

Aerosol therapy has a long history as a method used for the administration of drugs (1-3). In ancient times aerosols were obtained mainly from plants rich in tropane alkaloids (such as hyoscyamine, atropine and scopolamine) (4-8). The first data came from Ayurvedic medicine about 4,000 years ago. In ancient Egypt (approx. 1500 B.C.), papyrus scrolls containing a drawing presenting a patient inhaling vapours from incinerated Hyoscyamus niger (henbane) leaves were found in one of the Thebes pyramids (9-13). Anticholinergic properties of raw plant materials were described by the Indian physicians Charaka and Sushruta (approx. 600 B.C.), who recommended a method for obtaining a breathlessness relieving aerosol from $D$. stramonium herbs $(14,15)$. Some authors believe that smoking cigarettes made of $D$. stramonium leaves has a similar effect to taking bronchodilator drugs (4).

Another raw material in antiquity was Papaver somniferum, from which balsam and resin (opium) were obtained (16). In South and Central America (approx. 1500 B.C.) and

\footnotetext{
*Corresponding author: agata.krakowska@uj.edu.pl
} 
China (1100 B.C.), opium was smoked in pipes and the smoke was aspirated into the lungs. The medicinal properties of opium were much later described by Avicenna; that is, about 1025 A.D. According to Avicenna, opium had mainly analgesic and antidiarrheal properties, but it could be toxic and easily overdosed $(14,17)$.

Ephedra sinica (also called Ma Huang, and the medicinal substance it contained ephedrine) was a therapeutic plant popular in ancient China (1100 B.C.). Unlike other substances, Ma Huang could be taken orally (in the form of a herbal extract or pills) and was considered one of the most popular asthma therapeutics in the Roman Empire, particularly in combination with red wine (18). The popularity of ephedrine, which was isolated by Nagayoshi Nagai in 1885, lasted until the 20th century (the 1950s) when it was displaced

Table I. Raw materials used in aerosol therapy

\begin{tabular}{|c|c|c|c|}
\hline Region & Date & Plant/raw material used & Ref. \\
\hline India & 2000 B.C. & Datura stramonium & 5 \\
\hline Egypt & 1500 B.C. & Hyoscyamus niger & 10 \\
\hline Central America & 1500 B.C. & Papaver somniferum & 10 \\
\hline China & 1100 B.C. & Papaver somniferum & 10 \\
\hline China & 1100 B.C. & Ma Huang & 4 \\
\hline India & 600 B.C. & Datura stramonium & 10 \\
\hline Greece & 460 B.C. & Rhus coriaria, Anethum spp. & $\begin{array}{c}5 \\
10\end{array}$ \\
\hline Roman empire & 23-79 A.D. & $\begin{array}{l}\text { Ephedra sinica } \\
\text { Apium spp. }\end{array}$ & 10 \\
\hline Roman empire & 400-500 A.D. & Seawater & 10 \\
\hline Greece & 7th century A.D. & $\begin{array}{c}\text { Styrax spp., } \\
\text { Capsicum spp., } \\
\text { Pistacia lentiscus }\end{array}$ & $\begin{array}{c}5 \\
10\end{array}$ \\
\hline Arabia & 9th century A.D. & $\begin{array}{c}\text { D. stramonium, } \\
\text { H. niger } \\
\text { Mandragora oficinarum }\end{array}$ & 10 \\
\hline England & $\begin{array}{l}\text { 18th century A.D. } \\
\text { 19th century A.D. } \\
\text { 19th century A.D. }\end{array}$ & $\begin{array}{l}\text { Papaver somniferum } \\
\text { Iodine, Chlorine } \\
\text { Conium maculatum } \\
\text { Veratrum vide } \\
\text { Glycyrrhiza glabra } \\
\text { Phenolic acids }\end{array}$ & $\begin{array}{l}10 \\
10 \\
34\end{array}$ \\
\hline Europe & 20th century A.D. & $\begin{array}{l}\text { Camellia spp. } \\
\text { Atropa belladonna } \\
\text { D. stramonium }\end{array}$ & 35 \\
\hline
\end{tabular}


from medicine by more efficient substances (19). It should be added that attempts at constructing inhalation devices were made in ancient times.

In ancient Egypt, Ammi visnaga, rich in khellins, was used for inhalations. These compounds, known for such a long time, are nowadays used as precursors of cromoglycates, the use of which in asthma therapy began only in the 1960s $(4,20,21)$.

There is little information on the use of aerosol therapy from the fall of the Roman Empire to the Industrial Revolution (4th-18th century). The first mentions concern Caelius Aurelianus, a Roman physician who lived between the 4th and 5th century, and who recommended inhalation from steam and seawater for the therapy of numerous diseases, including asthma (10). In the 7th century, Paulus Egega catalogued numerous components recommended for inhalation to treat persistent cough and recommend aspiration through funnel evaporation of a mixture of i.a. resin, pepper, parsley. In the 9th century, the Persian physician Abu Bakr Muhammad ibn Zakarijja ar-Razi (also known as Rhazes) proposed a more innovative form of nebulization with the use of sponges which were soaked in a solution of narcotic drugs (i.a. Papaver somniferum, Hyoscyamus niger, Mandragora officinarum) and left to dry $(10,22,23)$.

Maimonides, a Spanish medic to the Egyptian sultan Saladin, made an undoubted contribution to the development of nebulization (12th century), he wrote the first book on asthma (A Treatise on Asthma), in which he recommended aspiration of an aerosol formed from herbs incinerated in the fire. He found the relationship between exposure to polluted air and the development of asthma $(24,25)$. Raw materials used in aerosol therapy are presented in Table I.

\section{Devices used for nebulization}

It should be added that attempts at constructing inhalation devices were made since ancient times. A highly innovative invention was developed by Hippocrates about 400 B.C. He invented a device reminiscent of a modern inhaler in terms of its structure. It consisted of a container and a cover with an opening, to which a reed was attached enabling inhalation $(4,14,20,20,26)$.

From the 17th century onwards, people began looking for devices for drug nebulization. English scholars, including Cristopher Bennet, John Mudge, and Philip Stern, who can be referred to as pioneers, had a vast impact on the development of inhalation techniques. In his book Theatri Tabidorum, Cristopher Bennet presents an apparatus reminiscent of a modern dry powder inhaler (DPI), the Turbohaler ${ }^{\circledR}(27)$. In the 18th century (1778) in his study A Radical and Expeditious Cure for a recent Catarrhous Cough, John Mudge used the word inhaler for the first time. On the other hand, Philip Stern recommended inhalation as the sole efficient manner of administering drugs to the lungs (14, 28).

In the 18th and 19th century there were many events worth noticing. In 1799, Thomas Beddoes established the Pneumatic Institute in Bristol (Clifton), one of the first units where patients were treated with inhalation. This is where the anesthetic properties of nitrogen oxide were demonstrated at the end of the 18th century $(18,29)$. In 1834, the English physician Francis Hopkins Ramadge constructed a device ('Ramadge Inhaling Pipe'), whose main component was a long glass pipe finished with a combustion chamber. This apparatus enabled the aspiration of vapours containing, for example: iodine, turpentine and 
other substances. In 1840, Sir Charles Scudamore, an English physician, recommended inhalation infusions based on iodine and Conium maculatum in lung diseases, including tuberculosis.

The first inhalational administration of anaesthetics, ethyl ether in 1846 was an important event that contributed to the development of aerosol therapy methods (30). This event resulted in anaesthetics being routinely used in surgical procedures. What is more important, people started looking for devices that would enable the administration of anaesthetic agents to patients, some of which although modified, are still used up to the present day (31).

In 1849 dr. Auphon Euget-Les Bain from France constructed a device producing aerosol as a result of mechanical disintegration of liquid particles; that is, atomization. Nine years later, in 1858, Jean Sales-Girons presented a portable atomizer named the 'pulverisateur'. His invention was characterized by a pump, which collected solution from a container and pumped it through a nozzle with a sprayer (5). In 1852, a physician from Boston, Ira Warren, patented the world's first inhaler with a design very similar to a dry powder inhaler (DPI). It comprised of two pipes. The first one was internal (with openings, into which the drug was placed), surrounded by another, an external pipe connected with a mouthpiece. With aspiration, the air movement rotated the internal pipe and produced an aerosol, thanks to which the drug was transported through the openings of the inner pipe to the respiratory tract. Interestingly, the device could be purchased with vials of inhalation powder (i.a. mercury and silver nitrate, copper sulphate) (10). It is worth adding that only slightly later, in 1864, Alfred Vincent Newton patented an inhaler that also generated aerosol from a suspension of dry powder. Although his device did not achieve commercial success, the constructor's assumptions in terms of the therapeutic substance placed inside the apparatus were highly significant. Newton observed that the powder must be fine and should be maintained in a dry state.

In 1862, the German physician Bergson constructed a device known as the Hydrokonium. It consisted of two pipes. The first was connected to a drug container, while the second to a set of two rubber blow bulbs that generated an air stream $(32,33)$. Several years later, another German scholar, dr. Emil Seigle, constructed a nebulizer which was one of the few that did not require external work to produce an aerosol. In this device, steam generated from a small boiler was used to disintegrate liquid into fine droplets, and two pipes were used through which the aerosol was released from the nebulizer. Siegle's steam atomizers were highly popular in the 19th century in Europe, the USA and Japan (33).

An interesting invention patented in 1889 was the Carbolic Smoke Ball, a rubber ball with a pipe attached to it, filled with a phenolic extract of herbs (Glycyrrhiza glabra, Veratrum spp.). When under pressure, the rubber ball released aerosol that could be used for inhalation of the upper respiratory tract. It aimed to be the efficient means to combat influenza, which was spreading in the 19th century. In addition, the advertisement for the Carbolic Smoke Ball included information that if any patient who underwent therapy with the use of the described device according to recommendations still became infected with influenza, the manufacturer would pay considerable amount of 100 pounds. Unfortunately, shortly after the advertisement was published, a female patient issued a claim for payment because her chasing with the Carbolic Smoke Ball proved ineffective. The case was resolved in court, where it was determined that offers made through an advertisement constituted a legal contract (34). 


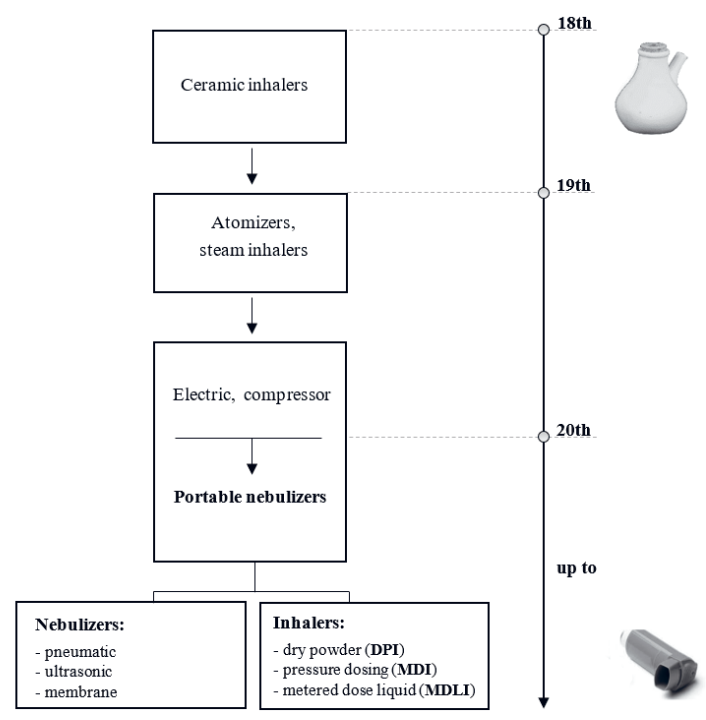

Fig. 1. Devices used for inhalation.

At the turn of the 19th and 20th centuries powders and herbal cigarettes used to treat asthma and other pulmonary diseases were highly popular. The cigarettes contained leaves of D. stramonium and other ingredients such as Camellia spp., and Atropa belladonna. In Poland, medicinal cigarettes known as Astmosan were available for purchase until the 1950s $(34,35)$.

The beginning of the 20th century also saw the advent of efficient drugs against respiratory tract diseases. One of these was adrenalin, which was first used by an American professor of medicine, Solomon da Silva Solis-Cohen, in 1900. Ten years later it was used in aerosolized form. It was available as a bronchodilator in the form of a hydrochloride solution (commercial name Asthma Nefrin) and in combination with papaverine (Bronchovydrin $\left.^{\circledR}\right)$. The use of bronchodilator drugs led to the creation of modern inhalers, which utilized a compressor to produce an aerosol (Pneumostat ${ }^{\circledR}$ ) and portable inhalers were also developed: Parke-Davis Glaseptic and De Vilbiss Glass Nebulizator. The latter was in use until the end of the 1950s when it was replaced by more modern devices $(36,5)$. The figure below (Fig. 1) presents inhalation devices from antiquity to the present day.

\section{Currently used inhaler types}

European Pharmacopoeia 10th Edition (monography Inhalandia precisely) distinguishes between nebulizers and inhalers. A nebulizer is a device that produces an aerosol, a suspension in which the dispersed phase is a liquid (containing a solution of a medicinal substance) and gas is the dispersion medium. Liquids solution for nebulisation $(\mathrm{pH} 3-8,5)$ could be also prepared from powders. A nebulizer produces aerosol in a continuous manner, it does not require aspiration to produce the aerosol, it is used with the elderly and small children (32). An inhaler typically has portable dimensions and enables the admini- 
stration of a precisely measured dose of a therapeutic substance (37-39). What is more, inhalers don't need propellant liquid or gas to produce an aerosol (43). Independently of the manner in which aerosol is formed, the main parameters characterizing the aerosolcloud (Fig. 2) are:

MAD - mass median aerodynamic diameter $(\mu \mathrm{m})$

FPF - fine particle fraction; the respirable fraction of particles with diameter $<5 \mu \mathrm{m}$

FPD - fine particle dose; a dose of the drug with diameter $<5 \mu \mathrm{m}$, dose of the deposited drug

GSD - geometric standard deviation; particle size distribution of aerosol (41-43).

One of the most commonly used inhalers is the dry powder inhaler (DPI). The dry powder inhaler was first used in 1948 for the inhalation of an antibiotic, penicillin (Aerohaler by $\mathrm{Abott}^{\circledR}$ ) (47). The principle of its operation consists of producing aerosol from powder. The patient's aspiration provides energy, producing shear forces and turbulence that disperse the drug in the form of powder. This phenomenon is also known as deagglomeration. Subsequently, the drug is transported to the lungs. The majority of DPIs contain a micronized drug (size 1-5 $\mu \mathrm{m}$ ) mixed with carrier particles, such as (most commonly) lactose, but also mannitol or sorbitol that prevent aggregation (45-48). Depending on the dosing system, DPIs can be divided into inhalers dosing a single dose of a drug (capsules made of hydroxy propyl methylcellulose or gelatin, such as Spiriva ${ }^{\circledR}$, HandiHaler $^{\circledR}$, Aerolizer $\left.^{\circledR}\right)$, devices dosing several single doses (blister packs, Anoro Ellipta ${ }^{\circledR}$ ) or multi-dose inhalers $\left(\right.$ Foradil $\left.{ }^{\circledR}\right)(49-53)$. Another highly important trait differentiation of dry powder inhalers is

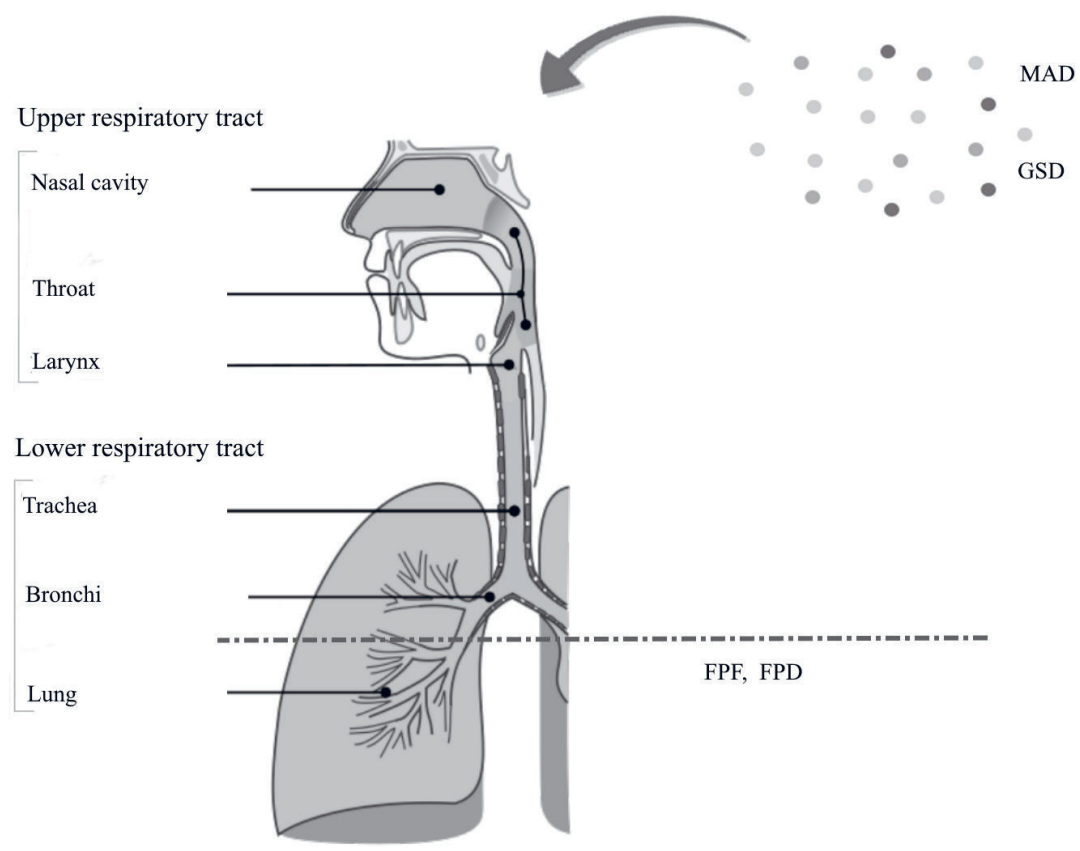

Fig. 2. Parameters characterizing an aerosol. 
Table II. Dry powder inhaler drug products

\begin{tabular}{|c|c|c|c|}
\hline $\begin{array}{l}\text { Brand name of } \\
\text { DPI inhalator }\end{array}$ & $\begin{array}{l}\text { Brand name of the } \\
\text { medicinal product }\end{array}$ & $\begin{array}{l}\text { Active pharmaceutical } \\
\text { ingredient }\end{array}$ & Dose $(\mu \mathrm{g})$ \\
\hline Aerolizer & Foradil & formoterol fumarate & 12 \\
\hline (Cyklohaler) & Miflonide & budesonide & 200,400 \\
\hline \multirow{4}{*}{ Breezhaler } & Seebri Breezhaler & glycopyrronium & 44 \\
\hline & Miflonide Breezhaler & budesonide & 200,400 \\
\hline & Onbrez Breezhaler & indacaterol & 150,300 \\
\hline & Ultibro Breezhaler & indacaterol + glycopyrronium & $85+43$ \\
\hline \multirow{5}{*}{ Dysk } & \multirow{5}{*}{$\begin{array}{l}\text { Flixotide Dysk } \\
\text { Seretide Dysk } \\
\text { Serevent Dysk } \\
\text { Ventolin Dysk }\end{array}$} & fluticasone propionate & $50,100,250,500$ \\
\hline & & fluticasone propionate + & $100+50$ \\
\hline & & salmeterol & $250+50$ \\
\hline & & salmeterol & $500+50$ \\
\hline & & salbutamol & 50,200 \\
\hline \multirow{5}{*}{ Easyhaler } & \multirow{5}{*}{$\begin{array}{l}\text { Budesonide Easyhaler } \\
\text { Bufomix Easyhaler } \\
\text { Buventol Easyhaler } \\
\text { Formoterol Easyhaler }\end{array}$} & budesonide & $100,200,400$ \\
\hline & & budesonide + formoterol & $160+4.5$ \\
\hline & & fumarate dihydrate & $320+9$ \\
\hline & & salbutamol & 100,200 \\
\hline & & formoterol & 12 \\
\hline \multirow{3}{*}{ Ellipta } & Relvar Ellipta & fluticasone furoate + vilanterol & $92+22,184+22$ \\
\hline & Incruse Ellipta & umeclidinum & 55 \\
\hline & Anoro Ellipta & umeclidinum + vilanterol & $55+25$ \\
\hline \multirow{2}{*}{ Forspiro } & \multirow{2}{*}{ AirFluSal Forspiro } & \multirow{2}{*}{$\begin{array}{c}\text { fluticasone propionate }+ \\
\text { salmeterol }\end{array}$} & $250+50$ \\
\hline & & & $500+50$ \\
\hline HandiHaler & Spiriva & tiotropium bromide & 18 \\
\hline NEXThaler & Fostex & $\begin{array}{l}\text { beclomethasone dipropionate, } \\
\text { formoterol fumarate dehydrate }\end{array}$ & $100+6$ \\
\hline \multirow{2}{*}{ Novolizer } & Budelin Novolizer & budesonide & 200 \\
\hline & Ventilastin Novolizer & salbutamol & 100 \\
\hline Podhaler & Tobi Podhaler & Tobramycin & 28000 \\
\hline \multirow{2}{*}{ Spiromax } & \multirow{2}{*}{ DuoResp Spiromax } & \multirow{2}{*}{$\begin{array}{l}\text { budesonide }+ \text { formoterol } \\
\text { fumarate dehydrate }\end{array}$} & $160+4.5$ \\
\hline & & & $320+9$ \\
\hline Twisthaler & Asmanex Twisthaler & mometasone furoate & 400 \\
\hline \multirow{4}{*}{ Turbuhaler } & \multirow{4}{*}{$\begin{array}{c}\text { Oxis Turbuhaler } \\
\text { Pulmicort Turbuhaler } \\
\text { Symbicort Turbuhaler }\end{array}$} & formoterol fumarate dihydrate & 4.5 \\
\hline & & budesonide & 200 \\
\hline & & budesonide + formoterol & $80+4.5$ \\
\hline & & fumarate dehydrate & $160+4.5$ \\
\hline Zonda & Braltus & Tiotropium & 10 \\
\hline
\end{tabular}


the inhaler's own resistance to the flowing air. Thus, DPIs differ in the values of aspiration flow interval values necessary to activate the drug dose $(54,55)$. In these terms, two types of dry powder inhalers can be distinguished: high resistance (optimum aspiration flow $>60 \mathrm{~L} / \mathrm{min}$, i.a. Turbohaler ${ }^{\circledR}$ ) and low resistance (aspiration flow 20-30 L min ${ }^{-1}$, i.a. HandiHaler $^{\circledR}$, Easyhaler $\left.{ }^{\circledR}\right)$ (56-59). It should be added that dry powder inhalers can administer large doses of the active pharmaceutical ingredient at a level higher than $25 \mathrm{mg}$

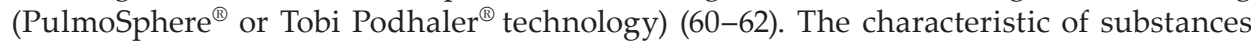
available with dry powder inhaler are presented in Table II.

There are many substances available with DPI inhalers. It can be divided into few pharmacological groups:

- short-acting $\beta$-adrenoreceptor agonists (salbutamol), acting up to 6 hours, usually used several times a day,

- long-acting $\beta$-adrenoreceptor agonists (salmeterol, formoterol), usually applied twice daily,

- ultra-long-acting $\beta$-adrenoreceptor agonists (indacaterol, vilanterol), acting 24 hours, allowing dosing once a day,

- steroids with anti-inflammatory properties (budesonide, fluticasone, beclomethasone), where dose depends on the severity of the disease and the individual response of the patient to treatment,

- short-acting muscarinic antagonist (ipratropium), which dosage depends on exacerbations of COPD,

- long-acting muscarinic antagonist (tiotropium, glycopyrronium) that are applied once daily $(63,64)$.

Another type of inhalers, metered-dose inhalers (MDI), were introduced to medicine at the end of the 1960s when DPI inhalers had already been known. Epinephrine (Medihaler Epi ${ }^{\circledR}$, Riker Laboratories) and isoprenaline (Medihaler Iso ${ }^{\circledR}$, Riker Laboratories) were the first drugs administered with this device type (10). MDIs comprise an approx. $100 \mathrm{~mL}$ container, in which the active substance is suspended or dissolved in a propellant, usually hydrofluoroalkanes (HFA-134a or HFA-227). Hydrofluoralkanes replaced more harmful to the environment chlorofluorocarbons more commonly known as the freons, which can be found in the older device. The outflow of the container consists of a triggering and dose metering mechanism, as well as a nozzle. Typically, the container is filled with pressurized gas (up to $>4 \mathrm{~atm}$ ) containing $20-500 \mu \mathrm{g}$ of a drug at doses between $25-100 \mu \mathrm{L}(65,66)$. The use of gasses that are harmless to the atmosphere, such as hydrofluoroalkanes (on the basis of the Montreal Protocol on substances that deplete the ozone layer) has resulted in a change to the formulation of the whole preparation. Apart from the drug and carrier gas, it is necessary to add surfactants and elastomer materials that would seal the valve releasing the drug dose (70). The use of pressurized gasses is the reason for the very high velocity of the aerosol stream (approx. $10 \mathrm{~m} \mathrm{~s}^{-1}$ ) released from the container. This may result in adverse events, primarily related to the deposition of the drug in the upper respiratory tract (throat, larynx), and thus produce hoarseness, local fungal infections (after glucocorticoid use) and the cold freon-effect; that is, spontaneous spasm of the upper airway muscles (mostly of the larynx) as a result of local cooling. This effect was more perceptible in the case of those inhalers containing freons (chlorofluorocarbons) as carrier gasses (68-70). Research shows that over half of patients are insufficiently informed about the proper use of inhalers (71-73). What is more, MDI misuse is observed in about $40-45 \%$ of patients (74, 
Table III. Pressurized metered-dose inhaler drug products

\begin{tabular}{cccc}
\hline $\begin{array}{c}\text { Brand name of the } \\
\text { medicinal product }\end{array}$ & $\begin{array}{c}\text { Active pharmaceutical } \\
\text { ingredient }\end{array}$ & Dose & Medical indication \\
\hline Alvesco & ciclesonide & $80 \mu \mathrm{g}, 160 \mu \mathrm{g}$ & Asthma \\
\hline Atimos & formoterol fumarate dihydrate & $12 \mu \mathrm{g}$ & Asthma, COPD \\
\hline Aspulmo, Ventolin, & salbutamol sulfate & $100 \mu \mathrm{g}$ & Asthma, Dyspnoea \\
\hline Antrovent N & tiotropium bromide & $20 \mu \mathrm{g}$ & Asthma, COPD \\
\hline Berotec N & fenoterol hydrobromide & $100 \mu \mathrm{g}$ & Asthma, COPD \\
\hline Berodual N & $\begin{array}{c}\text { fenoterol hydrobromide }+ \\
\text { ipratropium bromide }\end{array}$ & $50 \mu \mathrm{g}+20 \mu \mathrm{g}$ & Asthma, COPD \\
\hline Budiar, Ribuspir & budesonide & $200 \mu \mathrm{g}$ & Asthma \\
\hline Comboterol & $\begin{array}{c}\text { fluticasone furoate }+ \\
\text { salmeterol xinafoate }\end{array}$ & $\begin{array}{c}125 \mu \mathrm{g}+25 \mu \mathrm{g} \\
250 \mu \mathrm{g}+25 \mu \mathrm{g}\end{array}$ & Asthma \\
\hline Flixotide & fluticasone propionate & $50 \mu \mathrm{g}, 125 \mu \mathrm{g}$ & Asthma \\
\hline Fostex & $\begin{array}{c}\text { beclometasone dipropionate }+ \\
\text { formoterol fumarate dihydrate }\end{array}$ & $100 \mu \mathrm{g}+6 \mu \mathrm{g}$ & Asthma, COPD \\
\hline Seretide & $\begin{array}{l}\text { fluticasone furoate }+ \\
\text { salmeterol xinafoate }\end{array}$ & $\begin{array}{c}50 \mu \mathrm{g}+25 \mu \mathrm{g} \\
125 \mu \mathrm{g}+25 \mu \mathrm{g}\end{array}$ & Asthma, COPD \\
\hline Serevent & salmeterol xinafoate & $250 \mu \mathrm{g}+25 \mu \mathrm{g}$ & Asthma, COPD \\
\hline
\end{tabular}

75). Typical errors include the lack of coordination between aspiration and dose application, too shallow or rapid aspiration and the absence of a several-second holding of breath after drug administration (76-78). Errors during drug application considerably reduce the efficacy of therapy. These problems can be counteracted by means of proper patient education and through the use of spacers (79-81). When used, such spacers separate the aerosol cloud from its source, eliminating the above adverse events associated with the use of metered-dose inhalers (85). What is more, they may result in the aerosol being suspended for several seconds. Spacers are divided into: low-volume (i.a. Optimiser ${ }^{\circledR}$, Syncroner ${ }^{\circledR}$ ), medium-volume (Optichamber ${ }^{\circledR}$, Aerochamber $^{\circledR}$, Aerochamber Plus $^{\circledR}$, Nebuchamber $^{\circledR}$, Jet-spacer ${ }^{\circledR}$ ), and high-volume $\left(\right.$ Volumatic $^{\circledR}$, Fissonair $\left.^{\circledR}\right)$ (83-85). It has been assessed that MDI therapy with the use of spacers is equally efficient to nebulizer therapy (89). Characteristics of a drug available with metered-dose inhalers were listed in Table III.

There are few drugs that are available only with MDI inhalers. To this group belong short-acting $\beta$-agonists fenoterol, steroid ciclesonide and a drug used in exacerbations of asthma ipratropium bromide.

A metered-dose liquid inhaler (MDLI), also known as a soft mist inhaler (SMI), is used for the treatment of chronic obstructive pulmonary disease. In this device, an aerosol is formed by the pressure caused by a specially designed spring mechanism and the microchannels in the dosing chamber. MDLI, although utilizing a pressure mechanism for dose release, does not use carrier gasses (in contrast to MDI), and it also negates the patient's 
Table IV. Soft-mist inhaler drug products

\begin{tabular}{cccc}
\hline $\begin{array}{c}\text { Brand name of the } \\
\text { medicinal product }\end{array}$ & Active pharmaceutical ingredient & Dose $(\mu \mathrm{g})$ & Medical indication \\
\hline Spiriva Respimat & tiotropium & 2.5 & Asthma, COPD \\
\hline Spiolto Respimat & $\begin{array}{c}\text { tiotropium bromide monohydrate }+ \\
\text { olodaterol chloride }\end{array}$ & $2.5+2.5$ & COPD \\
\hline
\end{tabular}

need for aspiration effort. Furthermore, it offers higher lung deposition and a lower dose of the nominal drug than MDI.

During the dose application, the drug in the form of aqueous or ethanol solution is transported under high pressure of about 250 bar through the device head, creating an aerosol with a very high contribution of the deposited fraction (over $60 \%$ of aerosol particles are of $<5 \mu \mathrm{m}$ size) $(87,88)$. What is more, the water mist produced is released at a low velocity, which enhances drug deposition in the lungs (92). There are only few drugs equipped with MDLI, which are presenting in Table IV.

\section{Nebulizers (jet, ultrasonic, mesh)}

Nebulizers are used to produce aerosol composed of liquid dispersion of drug in a gas. In contrast, inhalers usually produce solid/gas dispersion. What differentiates nebulizers from inhalers is also the need for the electricity supply connection and the ability of passive drug application that does not require aspiration coordination. Nebulization is in particular used with small children, as well as patients who are in life-threatening condition (93). As a result of their different means of producing aerosol, they are divided into three main subtypes: pneumatic, ultrasonic and mesh nebulizers. In terms of design, the oldest nebulizers are jet and air-blast (pneumatic) nebulizers. A nebulizer is a term used for the entire device, that is the compressor, head (vessel for inhalation) and mouthpiece. The air that is compressed in the compressor is then transported through the nozzle and head and eventually forms an aerosol that can be emitted $(47,91,92)$. Theoretically, there is potential for combining any compressor with any nebulizer head; however, these elements should be precisely designed for one another. If these elements are not fully compatible, the formation of an aerosol with an incorrect particle size may result. What should also be emphasized is that the emitted aerosol has a polydisperse nature, meaning that it is characterized by particles of different shapes and sizes. Unfavourable distribution of the size of the liquid and gas suspension emitted is observed at the end of the effective aerosol formation when drops of considerable size start to appear and the phenomenon of sputtering occurs. It should be mentioned that not all of the available liquid undergoes atomization in compressor nebulizers. A certain amount of liquid always remains in the nebulizer head, which is not used in the nebulization process and this is referred to as dead volume (96). This may account for up to $40 \%$ of the initial fluid volume and primarily stems from the design of the head (86). What is more, due to the rapid expansion of gas particles at the end of the nozzle, a considerable solution temperature drop is observed (approx. $10-15^{\circ} \mathrm{C}$ ), which may result in a bronchospasm. Therefore, for most patients with lower respiratory tract hyperresponsiveness it is recommended to use a thermostat that would enable an aerosol with constant temperature to be obtained (97). 
Table V. Advantages and disadvantages of different types of inhalers and nebulizers

\begin{tabular}{|c|c|c|}
\hline Type of inhaler & Advantages & Disadvantages \\
\hline $\begin{array}{l}\text { Dry powder } \\
\text { inhalers (DPI) }\end{array}$ & $\begin{array}{l}\text { - small size } \\
\text { - simple construction } \\
\text { - acoustic and visual control of the dose taken } \\
\text { - always ready for use } \\
\text { - no carrier gases } \\
\text { - easy to clean } \\
\text { - fixed dose amount }\end{array}$ & $\begin{array}{l}\text { - activation of the device by the } \\
\text { patient's inhalation } \\
\text { - not all types of medication are } \\
\text { available } \\
\text { - susceptibility to moisture } \\
\text { - cannot be used by small children, } \\
\text { aged less than } 4 \text { years }\end{array}$ \\
\hline $\begin{array}{l}\text { Metered-dose } \\
\text { inhalers (MDI) }\end{array}$ & $\begin{array}{l}\text { - requires the patient to inhale upon actuation } \\
\text { - easy to use } \\
\text { - compact size } \\
\text { - multi-dose packaging } \\
\text { - resistance to weather conditions } \\
\text { - reliable } \\
\text { - no carrier gases } \\
\text { - high pulmonary deposition } \\
\text { - requires no effort from } \\
\text { respiratory system } \\
\text { - low speed of escaping aerosol } \\
\text { - small size } \\
\text { - dose counter }\end{array}$ & $\begin{array}{l}\text { - correct inhalation technique } \\
\text { required (coordination of inhalation } \\
\text { with drug application) } \\
\text { - significant drug deposition in the } \\
\text { upper respiratory tract } \\
\text { - no dose counter } \\
\text { - "cold freon effect" } \\
\text { - intended only for drugs soluble } \\
\text { in water or ethanol }\end{array}$ \\
\hline $\begin{array}{l}\text { Metered-dose } \\
\text { liquid inhalers } \\
\text { (MDLI) }\end{array}$ & $\begin{array}{l}\text { - no carrier gases } \\
\text { - high pulmonary deposition } \\
\text { - requires the patient to inhale upon actuation } \\
\text { - low speed of escaping aerosol } \\
\text { - small size } \\
\text { - dose counter }\end{array}$ & $\begin{array}{l}\text { - intended only for water or ethanol } \\
\text { drug solutions }\end{array}$ \\
\hline $\begin{array}{l}\text { Pneumatic/Jet } \\
\text { nebulizers }\end{array}$ & $\begin{array}{l}\text { - continuous operation } \\
\text { - suitable for all age groups of patients } \\
\text { - proper for all drugs } \\
\text { - insensitive to change of viscosity and } \\
\text { osmolarity of the liquid }\end{array}$ & $\begin{array}{l}\text { - large dead volume } \\
\text { - lowering of the temperature of the } \\
\text { solution during aerosol therapy } \\
\text { - device sterilization required } \\
\text { - large starting volume of nebuliser } \\
\text { solution } \\
(>2 \mathrm{~mL})\end{array}$ \\
\hline $\begin{array}{l}\text { Ultrasonic } \\
\text { nebulizers }\end{array}$ & $\begin{array}{l}\text { - high aerosol production capacity } \\
\text { - high sphericality and small size of the } \\
\text { produced droplets }\end{array}$ & $\begin{array}{l}\text { - only selected drugs can be used } \\
\text { - thermal degradation of sensitive } \\
\text { drugs }\end{array}$ \\
\hline $\begin{array}{l}\text { Mesh } \\
\text { nebulizers }\end{array}$ & $\begin{array}{l}\text { - portable } \\
\text { - high efficiency of aerosol respiratory } \\
\text { fraction production } \\
\text { - very low dead volume } \\
\text { - work quietly } \\
\text { - low power consumption } \\
\text { - can be used in a horizontal position } \\
\text { - short inhalation time }\end{array}$ & $\begin{array}{l}\text { - high cost } \\
\text { - unsuitable for high-density } \\
\text { solutions }\end{array}$ \\
\hline
\end{tabular}


Another type of these devices are ultrasonic nebulizers. The principle of their operation is based on the formation of a high-frequency acoustic wave (approx. 20,000 Hz) by means of a piezoelectric crystal. The high-energy acoustic wave reaches the liquid creating its waving and resulting in aerosol production (98). This is a polydisperse aerosol with a smaller and more spheral particle size than those obtained by pneumatic nebulizers (99). However, the generation of a high-energy wave often results in increased liquid temperature and drug inactivation (i.a. antibiotics, mucolytics). Therefore, this nebulizer type is only used to administer physiological saline solutions (100).

One of the latest introductions to medicine are vibrating-mesh nebulizers. The aerosol produced by these nebulizers is formed as a result of the passage of low-frequency waves (about $100 \mathrm{kHz}$, generated by a piezoelectric crystal) through a set of multiple micronozzles, openings (approx. 4,000) located on a common membrane (101). An undisputed advantage of this device is the production of a high-quality aerosol (fine particles, monodispersion) with a low initial velocity and high pulmonary deposition $(99,100)$. Furthermore, these devices are very small, have low energy consumption, and can be used in the horizontal position, without the need for a continuous power supply (99, 101-104). Vibrating-mesh nebulizers are expensive, and their cleaning is rather inconvenient (102). The advantages and disadvantages of the above devices are listed in the table below.

\section{New perspectives}

Nebulizers utilizing vibrating mesh technology are among the state-of-the-art commercially used devices. This type of device can be divided into passive (Omron ${ }^{\circledR}$ and Respironics ${ }^{\circledR}$, their principle of operation has been discussed in section 3) and active (Airon ${ }^{\circledR}$ and PARI ${ }^{\circledR}$ ) (111). In the latter, a set of micropumps is connected to a membrane, thanks to which the fluid is pressed through openings and transformed into an aerosol (112). Apart from the advantages of this type discussed in section 3 , special attention should be paid to the especially high efficiency of aerosol production, reduced drug use and possibility for performing different applications. In contrast to conventional nebulizers, vibrating mesh nebulizers enable the administration to patients of interferon-gamma (a technology utilizing double membranes, Photo-defined aperture plate, PDAP $^{\circledR}$ ), aerosol application in patients subject to mechanical ventilation and in infants (Aerogen Pro ${ }^{\circledR}$ and Aerogen Solo ${ }^{\circledR}$ ), and administration of a series of other drugs, including antibiotics (Amikacin Bayer HealthCare Pharmaceuticals $\left.{ }^{\circledR}\right)$, mucolytics and prostaglandins $(106,110)$.

Another direction for the development of aerosol therapy seems to be the inhalation administration of drugs, for which the application is associated with patient discomfort, such as insulin. In 2014, FDA approved a product called Afrezza ${ }^{\circledR}$, which is a fast-acting, recombinant insulin, used to treat both types I and II diabetes in patients without the pulmonary disease (asthma, COPD). It is available on the market as Afrezza Inhalation System with an inhaler and with three cartridges which differentiates according to colour and dosage: $4 \mathrm{U}$ (blue), $8 \mathrm{U}$ (green), and $12 \mathrm{U}$ (yellow). Afrezza ${ }^{\circledR}$ is a form of dry powder consisting of insulin in a form of technosphere (fumaryl diketopiperazine) microparticles that are absorbed in the lung and rapidly reach the bloodstream. It lowers blood glucose level faster than other injectable rapid-acting insulin (within 12-15 minutes) therefore it can be applied at mealtime. It has a short duration of action (up to 3 hours) therefore it can be easily combined with other types of insulin. In comparison with other inhalational 
insulin (e.g. Exubera $\left.{ }^{\circledR}\right)$, this preparation is characterized by considerably higher bioavailability and a more convenient inhaler and it does not require the calculation of the dose (mg per units/mL) $(114,115)$.

\section{CONCLUSIONS}

An efficient method for inhalational drug administration has been sought since ancient times. From antiquity to the modern era, the main raw materials used have been plants containing tropane alkaloids (such as Datura stramonium, Hyoscyamus niger and opium) with spasmolytic and analgesic effects. Rapid progress in aerosol therapy techniques has been observed since the 18th century when the word inhaler was first used. The invention of anaesthesia had an undoubted impact on the use of nebulization because this marked the start of the search for devices enabling efficient anaesthesia. It should be emphasized that the inhalation technique is one of the safest methods for drug administration and in some cases the only efficient one. The main adverse reactions stem from incorrect drug application techniques or inappropriate selection of device for the patient's needs. Therefore, from the second half of the 20th century, from the introduction of dry powder inhalers up to this day, the constant development of aerosol therapy methods has been noticed. Numerous modern inhalers have been implemented in therapy, such as metered-dose inhalers and liquid metered-dose inhalers. Moreover, vast improvement of nebulizers has been observed. These devices enable passive drug application in a continuous manner. It is very convenient especially for elderly people and small children. Currently, there are jet, ultrasonic and mesh nebulizers available on the market. Mesh nebulizers differ from other devices by producing aerosol with higher efficiency and the possibility of administration of selected drugs (antibiotics, mucolytics and prostaglandins). The future direction of aerosol therapy development seems to enable the administration of drugs seemingly impossible to apply or those whose application is associated with patient discomfort, such as insulin.

\section{REFERENCES}

1. A. Weiss, Symposium papers, Agron. J. 95 (2003) 1-3; https://doi.org/10.1016/j.niox.2004.07.002

2. L. Pitance, G. Reychler, T. Leal, H. Reychler, G. Liistro, J. Montharu, P. Diot and L. Vecellio, Aerosol delivery to the lung is more efficient using an extension with a standard jet nebulizer than an open-vent jet nebulizer, J. Aerosol Med. Pulmon. Drug Del. 26 (2013) 208-214; https://doi.org/10.1089/ jamp.2012.0994

3. G. Crompton, A brief history of inhaled asthma therapy over the last fifty years, Prim. Care Respir. J. 15 (2006) 326-331; https://doi.org/10.1016/j.pcrj.2006.09.002

4. S. D. Anderson, Repurposing drugs as inhaled therapies in asthma, Adv. Drug Del. Rev. 133 (2018) 19-33; https://doi.org/10.1016/j.addr.2018.06.006

5. P. J. Anderson, History of aerosol therapy: Liquid nebulization to MDIs to DPIs ceramic inhalers, Respir. Care 50 (2005) 1139-1149.

6. K. Fatur and S. Kreft, Common anticholinergic solanaceaous plants of temperate Europe - A review of intoxications from the literature (1966-2018), Toxicon 177 (2020) 52-88; https://doi. org/10.1016/j.toxicon.2020.02.005 
7. P. Soni, A. A. Siddiqui, J. Dwivedi and V. Soni, Pharmacological properties of Datura stramonium L. as a potential medicinal tree: An overview, Asian Pac. J. Trop. Biomed. 2 (2012) 1002-1008; https:// doi.org/10.1016/S2221-1691(13)60014-3

8. A. G. S. Pigatto, C. C. Blanco, L. A. Mentz and G. L. G. Soares, Tropane alkaloids and calystegines as chemotaxonomic markers in the Solanaceae, Anais Acad. Brasil. Cienc. 87 (2015) 2139-2149; https://doi.org/10.1590/0001-3765201520140231

9. P. K. Mukherjee, R. K. Harwansh, S. Bahadur, S. Banerjee, A. Kar, J. Chanda, S. Biswas, S. M. Ahmmed and C. K. Katiyar, Development of Ayurveda - Tradition to trend, J. Ethnopharm. 197 (2017) 10-24; https://doi.org/10.1016/j.jep.2016.09.024

10. S. W. Stein and C. G. Thiel, The history of therapeutic aerosols: A chronological review, J. Aerosol Med. Pulmon. Drug Del. 30 (2017) 20-41; https://doi.org/10.1089/jamp.2016.1297

11. S. Schläger and B. Dräger, Exploiting plant alkaloids, Curr. Opin. Biotechnol. 37 (2016) 155-164; https://doi.org/10.1016/j.copbio.2015.12.003

12. A. Alizadeh, M. Moshiri, J. Alizadeh and M. Balali-Mood, Black henbane and its toxicity - a descriptive review, Avicenna J. Phytomed. 4 (2014) 297-311; https://doi.org/10.22038/ajp.2014.3187

13. K. Fatur and S. Kreft, Common anticholinergic solanaceaous plants of temperate Europe - A review of intoxications from the literature (1966-2018), Toxicon 177 (2020) 52-88; https://doi. org/10.1016/j.toxicon.2020.02.005

14. M. Sanders, Inhalation therapy: An historical review, Prim. Care Respir. J. 16 (2007) 71-81; https:// doi.org/10.3132/pcrj.2007.00017

15. R. Arya, Ancient Indian concepts about phenomenology, biology, and therapeutics of epilepsy, J. Hist. Neurosci. 27 (2018) 56-71; https://doi.org/10.1080/0964704X.2017.1358039

16. M. A. Martínez and S. Ballesteros, Opium poisoning in modern times. An overview, Forensic Sci. Int. 302 (2019) 109848; https://doi.org/10.1016/j.forsciint.2019.06.006

17. K. Laios, K. Manes, M. Kontaxaki, M. Karamanou and G. Androutsos, Special Article, JAMA 87 (1926) 755; https://doi.org/10.1001/jama.1926.02680100039010

18. W. Thiesen, The letters of John Dastin, Ambix 55 (2008) 153-168; https://doi.org/10.1179/ $174582308 \times 255389$

19. M. G. Soni, I. G. Carabin, J. C. Griffiths and G. A. Burdock, Safety of ephedra: Lessons learned, Toxicol. Lett. 150 (2004) 97-110; https://doi.org/10.1016/j.toxlet.2003.07.006

20. A. E. Al-Snafi, A review of medicinal plants with broncho-dilatory effect - Part 1, Schol. Acad. J. Pharm. 5 (2016) 297-304; https://doi.org/10.21276/sajp.2016.5.7.6

21. N. Khalil, M. Bishr, S. Desouky and O. Salama, Ammi visnaga L., a potential medicinal plant: A review, Molecules 25 (2020) 1-18; https://doi.org/10.3390/molecules25020301

22. G. S. Mahmoudi Nezhad and B. Dalfardi, Rhazes (865-925 AD), the icon of Persian cardiology, Int. J. Cardiol. 177 (2014) 744-747; https://doi.org/10.1016/j.ijcard.2014.11.045

23. H. D. Modanlou, Medical care of children during the golden age of Islamic medicine, Arch. Iran. Med. 18 (2015) 263-265.

24. R. Beyar, K. Skorecki and S. Blazer, The Maimonides heritage: Discovery and propagation of medical knowledge, Rambam Maimonides Med. J. 9 (2018) 1-3; https://doi.org/10.5041/rmmj.10340

25. B. Gesundheit, Maimonides' appreciation for medicine, Rambam Maimonides Med. J. 2 (2011) 1-8; https://doi.org/10.5041/rmmj.10018

26. G. Tsoucalas and M. Sgantzos, Hippocrates, on the infection of the lower respiratory tract among the general population in ancient Greece, Gen. Med. Open Access 04 (2016) 1-5; https://doi. org/10.4172/2327-5146.1000272

27. K. Gourd, John Mudge, Lancet Respir. Med. 4 (2016) 16-17; https://doi.org/10.1016/S2213-2600(15)00422-1 
28. K. Nikander, C. Nicholls, J. Denyer and J. Pritchard, The evolution of spacers and valved holding chambers, J. Aerosol Med. Pulmon. Drug Del. 27 (2014) 4-23; https://doi.org/10.1089/jamp.2013.1076

29. T. H. Levere, T. H. Dr Thomas Beddoes: chemistry, medicine, and the perils of democracy, Notes and Records of the Royal Society of London, 63 (2009) 215-229; https://doi.org/10.1098/rsnr.2009.0032

30. D. H. Robinson and A. H. Toledo, Historical development of modern anesthesia, J. Invest. Surg. 25 (2012) 141-149; https://doi.org/10.3109/08941939.2012.690328

31. C. L. Mai and C. J. Coté, A history of pediatric anesthesia: A tale of pioneers and equipment, Paed. Anaesthesia 22 (2012) 511-520; https://doi.org/10.1111/j.1460-9592.2012.03828.x

32. H. M. Janssens and H. A. W. M. Tiddens, Aerosol therapy: The special needs of young children, Paediatr. Respir. Rev. 7 (2006) 83-85; https://doi.org/10.1016/j.prrv.2006.04.167

33. K. Nikander and M. Sanders, The early evolution of nebulizers, MedicaMundi 54 (2010) 47-53.

34. N. J. C. Snell, The carbolic smoke ball, Int. J. Pharm. Med. 15 (2001) 195-196; https://doi.org/10.1097/ 00124363-200108000-00006

35. M. Jackson, "Divine stramonium": The rise and fall of smoking for asthma, Med. Hist. 54 (2010) 171-194; https://doi.org/10.1017/S0025727300000235

36. C. Sorino, S. Negri, A. Spanevello, D. Visca and N. Scichilone, Inhalation therapy devices for the treatment of obstructive lung diseases: the history of inhalers towards the ideal inhaler, Eur. J. Inter. Med. 75 (2020) 15-18; https://doi.org/10.1016/j.ejim.2020.02.023

37. H. Chrystyn, D. B. Price, M. Molimard, J. Haughney, S. Bosnic-Anticevich, F. Lavorini, J. Efthimiou, D. Shan, E. Sims, A. Burden, C. Hutton and N. Roche, Comparison of serious inhaler technique errors made by device-naïve patients using three different dry powder inhalers: A randomised, crossover, open-label study, BMC Pulmon. Med. 16 (2016) 1-14; https://doi.org/10.1186/s12890-0160169-5

38. L. Vecellio, The mesh nebuliser, Breathe 2 (2006) 252-260; https://doi.org/ 10.1183/18106838.0203.252

39. D. P. Tashkin, A review of nebulized drug delivery in COPD, Int. J. COPD 11 (2016) 2585-2596; https://doi.org/10.2147/COPD.S114034

40. N. Islam and E. Gladki, Dry powder inhalers (DPIs) - A review of device reliability and innovation, Int. J. Pharm. 360 (2008) 1-11; https://doi.org/10.1016/j.ijpharm.2008.04.044

41. A. S. Melani, P. Canessa, I. Coloretti, G. Deangelis, R. Detullio, M. Del Donno, R. Giacobbe, I. Scarlato, A. Serafini, N. Barbato, A. Vaghi and P. Sestini, Inhaler mishandling is very common in patients with chronic airflow obstruction and long-term home nebuliser use, Respir. Med. 106 (2012) 668-676; https://doi.org/10.1016/j.rmed.2011.11.016

42. M. V. C. de Oliveira, E. Pizzichini, C. H. da Costa, C. C. Fritscher, E. O. Vianna, P. J. Z. Teixeira, R. Stirbulov, M. F. Rabahi and N. C. de Pinho, Evaluation of the preference, satisfaction and correct use of Breezhaler ${ }^{\circledR}$ and Respimat ${ }^{\circledR}$ inhalers in patients with chronic obstructive pulmonary disease - INHALATOR study, Respir. Med. 144 (2018) 61-67; https://doi.org/10.1016/j.rmed.2018.10.006

43. A. R. Clark, Medical aerosol inhalers: Past, present, and future, Aerosol Sci. Technol. 22 (1995) 374-391; https://doi.org/10.1080/02786829408959755

44. J. O. H. Sham, Y. Zhang, W. H. Finlay, W. H. Roa and R. Löbenberg, Formulation and characterization of spray-dried powders containing nanoparticles for aerosol delivery to the lung, Int. J. Pharmac. 269 (2004) 457-467; https://doi.org/10.1016/j.ijpharm.2003.09.041

45. P. Sheth, S. W. Stein and P. B. Myrdal, Factors influencing aerodynamic particle size distribution of suspension pressurized metered dose inhalers, AAPS PharmSciTech 16 (2014) 192-201; https:// doi.org/10.1208/s12249-014-0210-z

46. M. Yousefi, K. Inthavong and J. Tu, Effect of pressurized metered dose inhaler spray characteristics and particle size distribution on drug delivery efficiency, J. Aerosol Med. Pulmon. Drug Del. 30 (2017) 359-372; https://doi.or g/10.1089/jamp.2016.1299 
47. A. H. de Boer, P. Hagedoorn, M. Hoppentocht, F. Buttini, F. Grasmeijer and H. W. Frijlink, Dry powder inhalation: past, present and future, Exp. Opin. Drug Deliv. 14 (2017) 499-512; https://doi. org/10.1080/17425247.2016.1224846

48. M. L. Levy, W. Carroll, J. L. Izquierdo Alonso, C. Keller, F. Lavorini and L. Lehtimäki, Understanding dry powder inhalers: Key technical and patient preference attributes, Advan. Ther. 36 (2019) 02547-2557; https://doi.org/10.1007/s12325-019-01066-6

49. P. Mehta, Dry Powder Inhalers: A focus on advancements in novel drug delivery systems, J. Drug Deliv. 2016 (2016) 1-17; https://doi.org/10.1155/2016/8290963

50. M. J. Telko and A. J. Hickey, Dry powder inhaler formulation, Respir. Care 50 (2005) 1209-1227.

51. M. Ibrahim, R. Verma and L. Garcia-Contreras, Inhalation drug delivery devices: Technology update, Med. Devic. Evid. Res. 8 (2015) 131-139; https://doi.org/10.2147/MDER.S48888

52. P. Muralidharan, D. Hayes and H. M. Mansour, Dry powder inhalers in COPD, lung inflammation and pulmonary infections, Exp. Opin. Drug Deliv. 12 (2015) 947-962; https://doi.org/10.1517/174252 47.2015.977783

53. J. Perry, B. Trautman, J. Takher-Smith, S. Kramer, K. Kane, M. Silverman, L. Tan, S. Haughie, W. Richter, V. Kirkov, S. Arsova, J. Ward and D. L. Hava, Particle size and gastrointestinal absorption influence tiotropium pharmacokinetics: a pilot bioequivalence study of PUR0200 and Spiriva HandiHaler, Br. J. Clin. Pharmacol. 85 (2019) 580-589; https://doi.org/10.1111/bcp.13831

54. A. C. Grant, R. Walker, M. Hamilton and K. Garrill, The ELLIPTA ${ }^{\circledR}$ dry powder inhaler: Design, functionality, in vitro dosing performance and critical task compliance by patients and caregivers, J. Aerosol Med. Pulmon. Drug Del. 28 (2015) 474-485; https://doi.org/10.1089/jamp.2015.1223

55. D. Cada, K. Ingram, J. Leonard and D. Baker, Umeclidinium bromide and vilanterol trifenatate inhalation powder, Hosp. Pharm. 49 (2014) 554-562; https://doi.org/10.1310/hpj4906-554

56. N. J. Gross and J. F. Donohue, Nebulized formoterol: A review of clinical efficacy and safety in COPD, Int. J. Chron. Obstr. Pulmon. Dis. 5 (2010) 223-232; https://doi.org/10.2147/copd.s11006

57. D. R. Hess, Aerosol delivery devices in the treatment of asthma, Respir. Care 53 (2008) 699-723.

58. S. Ghosh, J. A. Ohar and M. B. Drummond, Peak inspiratory flow rate in chronic obstructive pulmonary disease: implications for dry powder inhalers, J. Aerosol Med. Pulmon. Drug Del. 30 (2017) 381-387; https://doi.org/10.1089/jamp.2017.1416

59. H. Mohammed, J. Arp, F. Chambers, M. Copley, V. Glaab, M. Hammond, D. Solomon, K. Bradford, T. Russell, Y. Sizer, S. C. Nichols, D. L. Roberts, C. Shelton, R. Greguletz and J. P. Mitchell, Investigation of Dry Powder Inhaler (DPI) resistance and aerosol dispersion timing on emitted aerosol aerodynamic particle sizing by multistage cascade impactor when sampled volume is reduced from compendial value of 4 L, AAPS PharmSciTech 15 (2014) 1126-1137; https://doi.org/10.1208/ s12249-014-0111-1

60. F. Lavorini, Easyhaler ${ }^{\circledR}$ : An overview of an inhaler device for day-to-day use in patients with asthma and chronic obstructive pulmonary disease, Drugs Context 8 (2019) 1-8; https://doi. org/10.7573/dic. 212596

61. J. Haikarainen, P. Rytilä, S. Roos, S. Metsärinne and A. Happonen, Dose uniformity of budesonide Easyhaler ${ }^{\circledR}$ under simulated real-life conditions and with low inspiration flow rates, Chron. Respir. Dis. 15 (2018) 265-271; https://doi.org/10.1177/1479972317745733

62. H. Chrystyn, Closer to an 'Ideal Inhaler' with the Easyhaler: an innovative dry powder inhaler, Clin. Drug Invest. 26 (2006) 175-183; https://doi.org/10.2165/00044011-200626040-00001

63. R. Scherließ and C. Etschmann, DPI formulations for high dose applications - Challenges and opportunities, Int. J. Pharm. 548 (2018) 49-53; https://doi.org/10.1016/j.ijpharm.2018.06.038

64. D. R. VanDevanter and D. E. Geller, Tobramycin administered by the TOBI ${ }^{\circledR}$ Podhaler ${ }^{\circledR}$ for persons with cystic fibrosis: A review, Med. Devices: Evid. Res. 4 (2011) 179-188; https://doi.org/10.2147/ MDER.S16360 
65. D. E. Geller, S. Z. Nasr, S. Piggott, E. He, G. Angyalosi and M. Higgins, Tobramycin inhalation powder in cystic fibrosis patients: Response by age group, Respir. Care 59 (2014) 388-398; https:// doi.org/10.4187/respcare.02264

66. L. Jacobson, Y. Okuda and S. A. Godwin, SimWars Simulation Case Book: Emergency Med., Cambridge University Press, 2015 pp. 89-92; https://doi.org/10.1017/CBO9781107111011.023

67. G. M. Keating, Tiotropium bromide inhalation powder, Drugs 72 (2012) 273-300; https://doi. org/10.2165/11208620-000000000-00000

68. S. P. Newman, Principles of metered-dose inhaler design, Respir. Care 50 (2005) 1177-1188.

69. C. Kleinstreuer, H. Shi and Z. Zhe, Computational analyses of a pressurized metered dose inhaler and a new drug-aerosol targeting methodology, J. Aerosol Med. 20 (2007) 294-309; https://doi. org/10.1089/jam.2006.0617

70. N. Roche and P. N. R. Dekhuijzen, The evolution of pressurized metered-dose inhalers from early to modern devices, J. Aerosol Med. Pulmon. Drug Del. 29 (2016) 311-327; https://doi.org/10.1089/ jamp.2015.1232

71. J. Sanchis, C. Corrigan, M. L. Levy and J. L. Viejo, Inhaler devices - From theory to practice, Respir. Med. 107 (2013) 495-502; https://doi.org/10.1016/j.rmed.2012.12.007

72. J. Goldberg, W. Böhning, P. Schmidt and E. Freund, Fenoterol hydrobromide delivered via HFAMDI or CFC-MDI in patients with asthma: A safety and efficacy comparison, Respir. Med. 94 (2000) 948-953; https://doi.org/10.1053/rmed.2000.0864

73. K. J. McDonald and G. P. Martin, Transition to CFC-free metered dose inhalers - Into the new millennium, Int. J. Pharm. 201 (2000) 89-107; https://doi.org/10.1016/S0378-5173(00)00401-4

74. M. Capanoglu, E. Dibek Misirlioglu, M. Toyran, E. Civelek and C. N. Kocabas, Evaluation of inhaler technique, adherence to therapy and their effect on disease control among children with asthma using metered dose or dry powder inhalers, J. Asthma 52 (2015) 838-845; https://doi.org/1 0.3109/02770903.2015.1028075

75. S. Barbara, V. Kritikos and S. B. Anticevich, Inhaler technique: Does age matter? A systematic review, Eur. Respir. Rev. 26 (2017) 1-10; https://doi.org/10.1183/16000617.0055-2017

76. G. Huchon, P. Hofbauer, G. Cannizzaro, P. Iacono and F. Wald, Comparison of the safety of drug delivery via HFA- and CFC-metered dose inhalers in CAO, Eur. Respir. J. 15 (2000) 663-669; https:// doi.org/10.1034/j.1399-3003.2000.15d07.x

77. R. J. Scarfone, G. A. Capraro, J. J. Zorc and H. Zhao, Demonstrated use of metered-dose inhalers and peak flow meters by children and adolescents with acute asthma exacerbations, Arch. Pediatr. Adol. Med. 156 (2002) 378-383; https://doi.org/10.1001/archpedi.156.4.378

78. S. L. Klijn, M. Hiligsmann, S. M. A. A. Evers, M. Román-Rodríguez, T. Van Der Molen and J. F. M. Van Boven, Effectiveness and success factors of educational inhaler technique interventions in asthma \& COPD patients: A systematic review, NPJ Prim. Care Respir. Med. 27 (2017) 1-10; https:// doi.org/10.1038/s41533-017-0022-1

79. J. Sanchis, I. Gich and S. Pedersen, Systematic review of errors in inhaler use: Has patient technique improved over time?, Chest 150 (2016) 394-406; https://doi.org/10.1016/j.chest.2016.03.041

80. J. W. H. Kocks, H. Chrystyn, J. van der Palen, M. Thomas, L. Yates, S. H. Landis, M. T. Driessen, M. Gokhale, R. Sharma and M. Molimard, Systematic review of association between critical errors in inhalation and health outcomes in asthma and COPD, npj Prim. Care Respir. Med. 28 (2018) 1-6; https://doi.org/10.1038/s41533-018-0110-x

81. H. AL-Jahdali, A. Ahmed, A. AL-Harbi, M. Khan, S. Baharoon, S. Bin Salih, R. Halwani and S. Al-Muhsen, Improper inhaler technique is associated with poor asthma control and frequent emergency department visits, Allergy Asthma Clin. Immunol. 9 (2013) 1-7; https://doi.org/10.1186/17101492-9-8 
82. J. P. Mitchell and M. W. Nagel, Valved holding chambers (VHCs) for use with pressurised metered-dose inhalers (pMDIs): A review of causes of inconsistent medication delivery, Prim. Care Respir. J. 16 (2007) 207-214; https://doi.org/10.3132/pcrj.2007.00034

83. M. Reznik, E. J. Silver and Y. Cao, Evaluation of MDI-spacer utilization and technique in caregivers of urban minority children with persistent asthma, J. Asthma 51 (2014) 149-154; https://doi.org /10.3109/02770903.2013.854379

84. S. D. Scott, M. H. Osmond, K. A. O'Leary, I. D. Graham, J. Grimshaw and T. Klassen, Barriers and supports to implementation of MDI/spacer use in nine Canadian pediatric emergency departments: A qualitative study, Implement. Sci. 4 (2009) 1-10; https://doi.org/10.1186/1748-5908-4-65

85. A. S. Melani, M. Bonavia, V. Cilenti, C. Cinti, M. Lodi, P. Martucci, M. Serra, N. Scichilone, P. Sestini, M. Aliani and M. Neri, Inhaler mishandling remains common in real life and is associated with reduced disease control, Respir. Med. 105 (2011) 930-938; https://doi.org/10.1016/j. rmed.2011.01.005

86. T. R. Sosnowski, Aerozole wziewne i inhalatory, Oficyna Wydawnicza Politechniki Warszawskiej, Warszawa 2010, pp. 73-111.

87. S. Dissanayake, M. Nagel, E. Falaschetti and J. Suggett, Are valved holding chambers (VHCs) interchangeable? An in vitro evaluation of VHC equivalence, Pulmon. Pharmacol. Ther. 48 (2018) 179-184; https://doi.org/10.1016/j.pupt.2017.10.005

88. D. Singh, S. Collarini, G. Poli, D. Acerbi, A. Amadasi and A. Rusca, Effect of AeroChamber Plus ${ }^{\mathrm{TM}}$ on the lung and systemic bioavailability of beclometasone dipropionate/formoterol pMDI, $B r$. J. Clin. Pharmacol. 72 (2011) 932-939; https://doi.org/10.1111/j.1365-2125.2011.04024.x

89. C. J. Cates, E. J. Welsh and B. H. Rowe, Holding chambers (spacers) versus nebulisers for beta-agonist treatment of acute asthma, Cochrane Database System. Rev. 9 (2013) 1-94; https://doi. org/10.1002/ 14651858.CD000052

90. T. Iwanaga, Y. Tohda, S. Nakamura and Y. Suga, The Respimat ${ }^{\circledR}$ soft mist inhaler: Implications of drug delivery characteristics for patients, Clin. Drug Invest. 39 (2019) 1021-1030; https://doi. org/10.1007/s40261-019-00835-z

91. H. A. Blair, Tiotropium/olodaterol: A review in COPD, Drugs 79 (2019) 997-1008; https://doi. org/10.1007/s40265-019-01133-w

92. P. Brand, B. Hederer, G. Austen, H. Dewberry and T. Meyer, Higher lung deposition with Respimat ${ }^{\circledR}$ Soft Mist ${ }^{\mathrm{TM}}$ Inhaler than HFA-MDI in COPD patients with poor technique, Int. J. COPD 3 (2008) 763-770; https://doi.org/10.2147/COPD.S3930

93. C. Smith and R. D. Goldman, Nebulizers versus pressurized metered-dose inhalers in preschool children with wheezing, Can. Fam. Physic. 58 (2012) 528-530.

94. A. Ari, Aerosol therapy in pulmonary critical care, Respir. Care 60 (2015) 858-874; https://doi. org/10.4187/respcare.03790

95. M. Najlah, A. Vali, M. Taylor, B. T. Arafat, W. Ahmed, D. A. Phoenix, K. M. G. Taylor and A. Elhissi, A study of the effects of sodium halides on the performance of air-jet and vibrating-mesh nebulizers, Int. J. Pharm. 456 (2013) 520-527; https://doi.org/10.1016/j.ijpharm.2013.08.023

96. N. Collins, Nebulizer therapy in cystic fibrosis: An overview, J. Roy. Soc. Med., Suppl. 102 (2009) 11-17; https://doi.org/10.1258/jrsm.2009.s19003

97. M. Ochowiak, A. Kasperkowiak, M. Doligalski, T. R. Sosnowski, M. Matuszak, S. Włodarczak, M. Markowska, A. Krupińska and K. Jabłczyńska, The thermostated medical jet nebulizer: Aerosol characteristics, Int. J. Pharm. 567 (2019) 1-10; https://doi.org/10.1016/j.ijpharm.2019.118475

98. M. P. Flament, P. Leterme and A. Gayot, Study of the technological parameters of ultrasonic nebulization, Drug Develop. Ind. Pharm. 27 (2001) 643-649; https://doi.org/10.1081/DDC-100107320

99. L. Broniarz-Press, T. R. Sosnowski, M. Matuszak, M. Ochowiak and K. Jabłczyńska, The effect of shear and extensional viscosities on atomization of Newtonian and non-Newtonian fluids in ultrasonic inhaler, Int. J. Pharm. 485 (2015) 41-49; https://doi.org/10.1016/j.ijpharm.2015.02.065 
100. J. Y. Boyden, S. R. Connor, L. Otolorin, S. D. Nathan, P. G. Fine, M. S. Davis and J. C. Muir, Nebulized medications for the treatment of dyspnea: A literature review, J. Aerosol Med. Pulmon. Drug Del. 28 (2015) 1-19; https://doi.org/10.1089/jamp.2014.1136

101. V. C. Galindo-Filho, L. Alcoforado, C. Rattes, D. N. Paiva, S. C. S. Brandão, J. B. Fink and A. Dornelas de Andrade, A mesh nebulizer is more effective than jet nebulizer to nebulize bronchodilators during non-invasive ventilation of subjects with COPD: A randomized controlled trial with radiolabeled aerosols, Respir. Med. 153 (2019) 60-67; https://doi.org/10.1016/j.rmed.2019.05.016

102. M. Baravalle-Einaudi, N. Dufeu, C. Dupont, L. Vecellio, B. Delaisi, A. Carsin and J. C. Dubus, Vibrating-mesh nebulizer maintenance by CF patients: Results from a French survey, Pulmon. Pharmacol. Ther. 44 (2017) 57-60; https://doi.org/10.1016/j.pupt.2017.03.011

103. R. B. Dunne and S. Shortt, Comparison of bronchodilator administration with vibrating mesh nebulizer and standard jet nebulizer in the emergency department, Am. J. Emerg. Med. 36 (2018) 641-646; https://doi.org/10.1016/j.ajem.2017.10.067

104. M. N. Dubosky, Y. F. Chen, M. E. Henriksen and D. L. Vines, Vibrating mesh nebulizer compared with metered-dose inhaler in mechanically ventilated subjects, Respir. Care 62 (2017) 391-395; https://doi.org/10.4187/respcare.04823

105. Ö. Soyer, M. Kahveci, B. Büyüktiryaki, E. Arik Yilmaz, B. Karaatmaca, S. Esenboğa, P. Gür Çetinkaya, Ü. M. Şahiner and B. E. Şekerel, Mesh nebulizer is as effective as jet nebulizer in clinical practice of acute asthma in children, Turk. J. Med. Sci. 49 (2019) 1008-1013; https://doi. org/10.3906/sag-1812-133

106. N. Murayama and K. Murayama, Comparison of the clinical efficacy of salbutamol with jet and mesh nebulizers in asthmatic children, Pulmon. Med. 2018 (2018) 1-6; https://doi. org/10.1155/2018/1648652

107. A. Ari, O. T. Atalay, R. Harwood, M. M. Sheard, E. A. Aljamhan and J. B. Fink, Influence of nebulizer type, position, and bias flow on aerosol drug delivery in simulated pediatric and adult lung models during mechanical ventilation, Respir. Care 55 (2010) 845-851.

108. M. M. Al-Tabakha, Future prospect of insulin inhalation for diabetic patients: The case of Afrezza versus Exubera, J. Control. Release 215 (2015) 25-38; https://doi.org/10.1016/j.jconrel.2015.07.025

109. J. N. Pritchard, R. H. M. Hatley, J. Denyer and Di. Von Hollen, Mesh nebulizers have become the first choice for new nebulized pharmaceutical drug developments, Ther. Deliv. 9 (2018) 121-136; https://doi.org/10.4155/tde-2017-0102

110. M. Keller, Innovations and perspectives of metered dose inhalers in pulmonary drug delivery, Int. J. Pharm. 186 (1999) 81-90; https://doi.org/10.1016/S0378-5173(99)00132-5

111. A. A. Gowda, A. D. Cuccia and G. C. Smaldone, Reliability of vibrating mesh technology, Respir. Care 62 (2017) 65-69; https://doi.org/10.4187/respcare.04702

112. T. Ghazanfari, A. M. A. Elhissi, Z. Ding and K. M. G. Taylor, The influence of fluid physicochemical properties on vibrating-mesh nebulization, Int. J. Pharm. 339 (2007) 103-111; https://doi.org/ 10.1016/j.ijpharm.2007.02.035

113. L. Sweeney, A. P. McCloskey, G. Higgins, J. M. Ramsey, S. A. Cryan and R. MacLoughlin, Effective nebulization of interferon- $\gamma$ using a novel vibrating mesh, Respir. Res. 20 (2019) 1-11; https:// doi.org/10.1186/s12931-019-1030-1

114. R. R. Mohanty and S. Das, Inhaled insulin - current direction of insulin research, J. Clin. Diagn. Res. 11 (2017) 1-2; https://doi.org/10.7860/JCDR/2017/23626.9732

115. Pettus, T. Santos Cavaiola and S. V. Edelman, Recommendations for initiating use of afrezza inhaled insulin in individuals with type 1 diabetes, Diabetes Technol. Ther. 20 (2018) 448-451; https://doi.org/10.1089/dia.2017.0463 